\title{
Estimation of Exponential Smoothing Parameter on Pesticide Characteristic Forecast using Ant Colony Optimization (ACO)
}

\section{Dinita Rahmalia}

\author{
Program Studi Matematika, Universitas Islam Darul Ulum, Lamongan, 62253, \\ dinitarahmalia@gmail.com, \\ Phone : 085730016452
}

\begin{abstract}
Pest in agriculture can raise plant disease and fail to harvest. The pest problem in agriculture can be solved by using pesticide. Pesticide usage must be done proportionally. Therefore, the manufacturer should fix standard pesticide active ingredient in pesticide production. Forecasting is a prediction of some future evens. In forecast problem, there are any parameters which should be estimated. Parameters can be estimated by exact or heuristic methods. Ant Colony Optimization (ACO) is one of the heuristic method inspired by the cooperative behavior of ant colonies, to find the shortest path from their nest to the food source. In this research, we use heuristic method like ACO to estimate the exponential smoothing parameter on pesticides active ingredient and sample weight forecasts. Based on the simulation, where at the first iteration, all ants choose parameter randomly, the optimization process, we update pheromone until all ants choose the similar parameter such that the process converges and the variance approaches to zero. The optimal exponential smoothing parameter can be applied in forecasting to minimize sum of squared error (SSE). The results of simulations are optimal exponential smoothing parameter is 0,9 and SSE of pesticide active ingredient and sample weight forecasts are 0,77 and 194,34 respectively.
\end{abstract}

Keywords: Parameter estimation; Ant Colony Optimization; Exponential Smoothing

\begin{abstract}
ABSTRAK
Hama pertanian dapat menyebabkan penyakit tanaman dan gagal panen. Masalah hama dapat dikendalikan dengan penggunaan pestisida. Penggunaan pestisida harus dilakukan secara proporsional sehingga perusahaan pestisida harus menetapkan standar kadar bahan aktif pestisida dalam produksinya. Peramalan adalah memprediksi kejadian yang akan datang. Pada masalah peramalan, terdapat parameter yang harus ditetapkan. Parameter dapat diestimasi menggunakan metode eksak maupun metode heuristik. Ant Colony Optimization (ACO) teriinspirasi dari perilaku koloni semut yang dapat menemukan jalan terbaik dari sarang menuju sumber makanan. Pada penelitian ini, akan digunakan metode heuristik seperti ACO untuk mengestimasi parameter exponential smoothing pada peramalan kadar bahan aktif pestisida dan peramalan berat contoh pestisida. Dari hasil simulasi, pada iterasi awal, koloni semut memilih parameter secara acak. Pada proses optimisasi, pheromone diupdate dan koloni semut memilih parameter yang sama sehingga proses konvergen dan variansi mendekati nol. Parameter exponential smoothing yang optimal dapat diterapkan pada peramalan yang meminimumkan sum of squared error (SSE). Hasil simulasi adalah parameter exponential smoothing
\end{abstract}

Estimation of Exponential Smoothing Parameter on Pesticide Characteristic Forecast using Ant Colony Optimization (ACO) 
optimal adalah 0,9 dan nilai SSE dari peramalan kadar bahan aktif dan berat contoh pestisida adalah 0,77 dan 194,34 berturut-turut.

Kata-kata Kunci: Estimasi parameter, Ant Colony Optimization, Exponential Smoothing

\section{Introduction}

Pest is an organism which harms agriculture and cause the damage of population. Pest in agriculture can raise plant disease and fail to harvest. The pest problem in agriculture can be solved by using pesticide.

Pesticide usage must be done proportionally. Less pesticide can cause pest still grow up and devastate plant. However, more pesticide will suffer the plant although the pests have lost. Therefore, the manufacturer should fix standard pesticide active ingredient in pesticide production.

Forecasting is a prediction of some future evens. In forecasting problem, there are any parameters which should be estimated. Generally, parameter of forecasting equation can be applied or choosen by trial and error and parameter estimation using the exact method such as least square estimation have been applied (Montgomery, 2015). Beside exact method, heuristic method can be used in estimating parameter of forecasting (Elvural et al., 2016; Wu and Chang, 2002). Heuristic method used in this research is Ant Colony Optimization (ACO).

Ant Colony Optimization (ACO) is inspired from the cooperative behavior of ant colonies, which can find the shortest path from their nest to a food source. The method was developed by Dorigo in 1990 (Dorigo and Stutzle, 2004). In previous research, ACO method have been applied on optimization problem (Rao, 2012; Rahmalia and Herlambang, 2017). In this research, we use ACO to estimate the exponential smoothing parameter on pesticides active ingredient and sample weight forecasts.

In simulation, at the first iteration, all ants choose parameter randomly. At the optimization process, we update the pheromone until all ants choose the similar parameter such that the process converges and the variance approaches to zero. After that, we will obtain the optimal exponential smoothing parameter. The optimal exponential smoothing parameter can be applied in forecasting where the sum of squared error (SSE) will be minimum.

\section{First Order Exponential Smoothing}

The simple exponential smoothing is represented as in equation (1) (Montgomery, 2015) :

$$
f_{t}=\lambda y_{t}+(1-\lambda) f_{t-1} \quad t=1,2, \ldots . T
$$


with initialization in equation (2)

$$
f_{0}=\frac{1}{T} \sum_{t} y_{t}
$$

and the equation can be explained :

$f_{t}$ : forecast of the time series for period $t$

$y_{t}$ : actual value of the time series for period $t$

$\lambda$ : smoothing parameter $(0 \leq \lambda \leq 1)$

The objective is to minimize the sum of squared error (SSE), subject to the smoothing parameter requirement $(0 \leq \lambda \leq 1)$ as the decision variable in equation (3) (Anderson, 2012). In other words

$$
\min S S E=\sum_{t=0}^{T}\left(y_{t}-f_{t}\right)^{2}
$$

subject to :

$f_{t}=\lambda y_{t}+(1-\lambda) f_{t-1} \quad t=1,2, \ldots . T$

$f_{0}=\frac{1}{T} \sum_{t} y_{t}$

$(0 \leq \lambda \leq 1)$

The optimization problem above can be solved by implemented the exponential smoothing algorithm (ex_smoothing $(\lambda)$ ) as follows :

$$
\text { ex_smoothing }(\lambda)
$$

1. Set initial forecast by the average of the available data or a subset of the available data

$$
f_{0}=\frac{1}{T} \sum_{t} y_{t}
$$

2. Compute recursively

$$
f_{t}=\lambda y_{t}+(1-\lambda) f_{t-1} t=1,2, \ldots . T
$$

3. Find the sum of the squared error (SSE)

$$
S S E=\sum_{t=0}^{T}\left(y_{t}-f_{t}\right)^{2}
$$

\section{Ant Colony Optimization (ACO)}

ACO process can be explained as follows : the ants start at the home node, travel through the various layers from the first layer to the last or final layer, and stop at the destination node in each cycle or iteration.

In the beginning of the optimization process, all edges are initialized with an equal amount of pheromone. All the ants start from the home node and stop at the destination node by randomly selecting a node in each layer. In general, at the optimum solution, all ants travel along the same best (converged) path.

There are three steps in ACO process : ant searching behavior, pheromone trail evaporation, and path retracing and pheromone updating (Rao, 2009).

\section{Ant Searching Behavior}

In equation (4), an ant $k$, when located at node $i$, uses the pheromone trail $\tau_{i j}$ to compute the probability of choosing $j$ as the next node

$$
p_{i j}^{(k)}=\left\{\begin{array}{cc}
\frac{\tau_{i j}^{\alpha}}{\sum_{j \in N_{i}(k) \tau_{i j}^{\alpha}}} & \text { if } j \in N_{i}^{(k)} \\
0 & \text { if } j \in N_{i}^{(k)}
\end{array}\right.
$$

Where $\alpha$ denotes the degree of importance of the pheromone and $N_{i}^{(k)}$ indicates the set of

Estimation of Exponential Smoothing Parameter on Pesticide Characteristic Forecast using Ant Colony Optimization (ACO) 
neighborhood nodes of ant $k$ when located at node $i$.

\section{Pheromone Trail Evaporation}

When an ant $k$ moves to the next node, the pheromone evaporates from all the arcs $i j$ according to equation (5) :

$$
\tau_{i j} \leftarrow(1-\rho) \tau_{i j} \quad \forall(i, j) \in A
$$

Where $\rho \in(0,1]$ is a parameter and $A$ denotes the segments or arcs traveled by ant $k$ in its path from home to destination.

After all the ants return to the home (nest), the pheromone information is updated according to the equation (6) :

$$
\tau_{i j} \leftarrow(1-\rho) \tau_{i j}+\sum_{k=1}^{N} \Delta \tau_{i j}{ }^{(k)}
$$

Where $\rho \in(0,1]$ is the evaporation rate (pheromone decay factor) and $\Delta \tau^{(k)}$ is the amount of pheromone deposited on arc $i j$ by the best ant $k$.

The pheromone deposited on arc $i j$ by the best ant is taken as in equation (7)

$$
\sum \Delta \tau_{i j}^{R}=\left\{\begin{array}{cc}
N_{b e s t}, \frac{Q}{f_{b e s t}}, & \text { if }(i, j) \text { is the best } \\
0, & \text { othenwise }
\end{array}\right.
$$

where $Q$ is a constant

3. Path Retracing and Pheromone Updating The pheromone value $\tau_{i j}$ on the $\operatorname{arc}(i, j)$ traversed is updated. Because of the increasing in the pheromone, the probability of this arc being selected by the forthcoming ants will increase .

\section{Overall Algorithm}

The algorithm of determining optimal parameter using ACO can be constructed as follows :

1. Set the number of ants $N$ and the pheromone decay factor $\rho$.

2. In equation (8), generate $M$ possible parameter $0 \leq \lambda \leq 1$ and give the probability uniformly.

$$
p\left(\lambda_{i}\right)=\frac{1}{M}, \quad i=1,2, \ldots, M
$$

3. Calculate cumulative probability range $C_{i}$

4. Generate random variable $r_{s} \sim U(0,1)$ $s=1,2, \ldots, N$.

5. Determine selected parameter $\lambda_{i}, i \in\{1,2, \ldots, M\}$ and for every ant $s$.

6. Calculate objective function $e x_{-}$smoothing $\left(\lambda_{i}\right)$ for every ant $s$.

7. Choose minimum fitness function $f_{\text {best }}=\min \left(\right.$ ex_smoothing $\left.\left(\lambda_{i}\right), i \in\{1,2, \ldots, M\}\right)$ , and count $N_{\text {best }}$, the number of $f_{\text {best }}$

8. In equation (9), set constant $Q$ and calculate $\sum \Delta \tau\left(\lambda_{i}\right), i=1,2, \ldots, M$

$$
\sum \Delta \tau\left(\lambda_{i}\right)=\left\{\begin{array}{rc}
N_{b e s t} \frac{Q}{f_{b e s t},}, & \text { if } \lambda_{i} \text { is the best parameter } \\
0, & \text { otherwise }
\end{array}\right.
$$

9. Update the pheromone as in equation (10)

$$
\tau_{i}=(1-\rho) \tau_{i}+\sum \Delta \tau\left(\lambda_{i}\right) i=1,2, \ldots, M
$$


10. Update the pheromone probability as in equation (11)

$$
p\left(\lambda_{i}\right)=\frac{\tau_{i}}{\sum \tau_{i}} \quad i=1,2, \ldots, M
$$

11. Repeat step 3-10 until all ants choose the simular parameter and such that the process converges and the variance approaches to zero.

\section{Materials and Methods}

Data are obtained from one of the pesticide manufacturer company in Gresik, East Java. Data used in this research are pesticide active ingredient data (\%) and pesticide sample weight data (miligram) during January-July 2009 (Rahmalia, 2009). Simulations are applied by Matlab. From each data, ACO will be applied for estimating exponential smoothing parameter.

\section{Simulation and Discussion}

The ACO parameters such as the number of ants, the range of parameter, pheromone decay factor, and maximum iteration of estimating exponential smoothing parameter on pesticide active ingredient forecast are given in Table 1.

Figure 2 shows the time series of pesticide active ingredient (\%) during January-July 2009. From actual value of time series, we will forecast using exponential smoothing method.
Figure 3 shows optimization process ACO in estimating exponential smoothing parameter on pesticide active ingredient forecast. On the first iteration, all ants choose parameter randomly so that variance is relatively high. At the optimization process, we update pheromone until all ants choose the similar parameter so that process converges and variance approaches to zero.

After ACO is applied until maximum iteration, we obtain the optimal exponential smoothing parameter is 0.9 . The optimal exponential parameter is applied in forecasting such that the simulation can be seen in Figure 4 with sum of the squared error (SSE) is 0.77 .

Table 1. ACO parameter of estimating exponential smoothing parameter on pesticide active ingredient forecast

\begin{tabular}{lc}
\hline The number of ants & 100 \\
\hline The range of parameter & $(0-1)$ \\
\hline Pheromone decay factor & 0.9 \\
\hline Maximum iteration & 50 \\
\hline
\end{tabular}

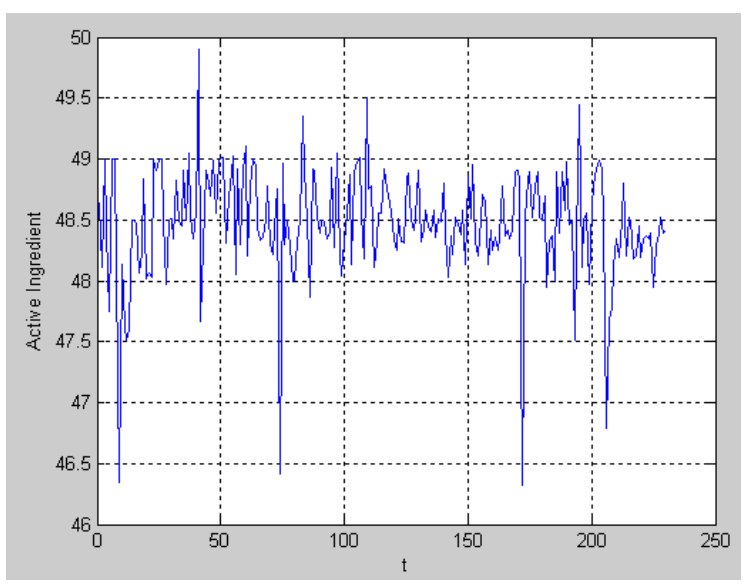

Figure 2. Time series of pesticide active ingredient

Estimation of Exponential Smoothing Parameter on Pesticide Characteristic Forecast using Ant Colony Optimization (ACO) 


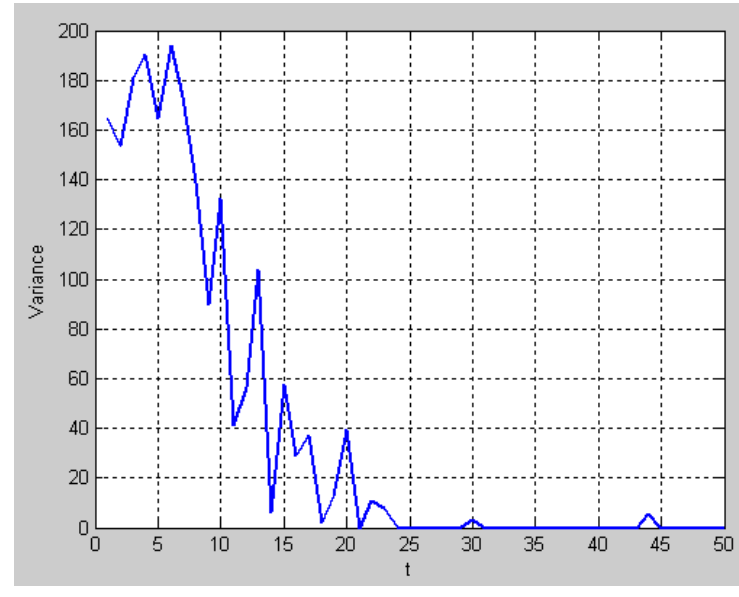

Figure 3. Simulation ACO in estimating exponential smoothing parameter on pesticide active ingredient forecast

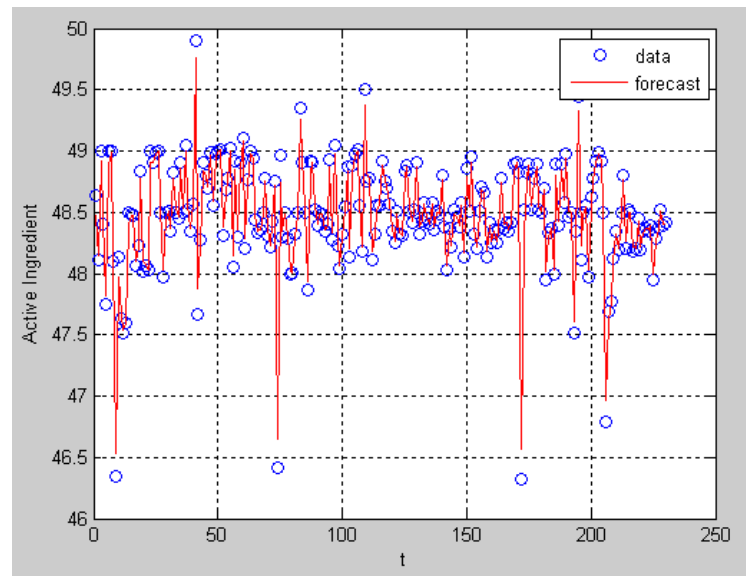

Figure 4. Forecast result of pesticide active ingredient

The ACO parameters such as the number of ants, the range of parameter, pheromone decay factor, and maximum iteration of estimating exponential smoothing parameter on pesticide sample weight forecast are given in Table 2.

Figure 5 shows the time series of pesticide sample weight (miligram) during January-July 2009. From actual value of time series, we will forecast using exponential smoothing method.
Figure 6 shows optimization process ACO in estimating exponential smoothing parameter on pesticide sample weight forecast. On the first iteration, all ants choose parameter randomly so that variance is relatively high. At the optimization process, we update pheromone until all ants choose the similar parameter so that process converges and variance approaches to zero.

After ACO is applied until maximum iteration, we obtain the optimal exponential smoothing parameter is 0.9 . The optimal exponential parameter is applied in forecasting such that the simulation can be seen in Figure 7 with sum of the squared error (SSE) is 194.34.

Table 2. ACO parameter of estimating exponential smoothing parameter on pesticide sample weight forecast

\begin{tabular}{lc}
\hline The number of ants & 100 \\
\hline The range of parameter & $(0-1)$ \\
\hline Pheromone decay factor & 0.9 \\
\hline Maximum iteration & 100 \\
\hline
\end{tabular}

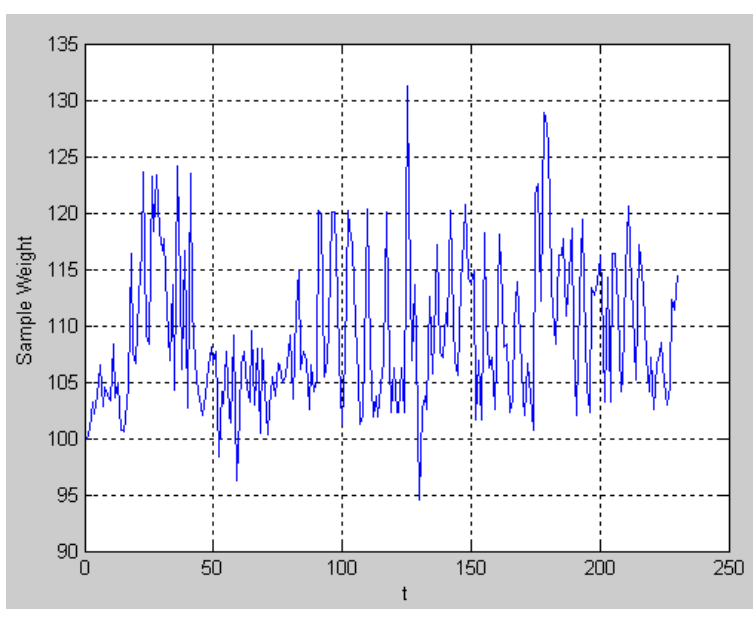

Figure 5 Time series of pesticide sample weight

Estimation of Exponential Smoothing Parameter on Pesticide Characteristic Forecast using Ant Colony Optimization (ACO) 


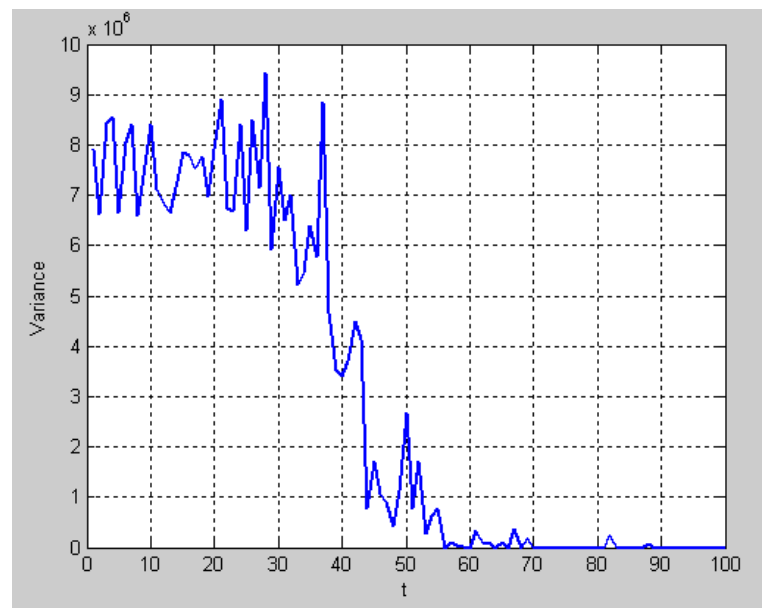

Figure 6. Simulation ACO in estimating exponential smoothing parameter on pesticide sample weight forecast

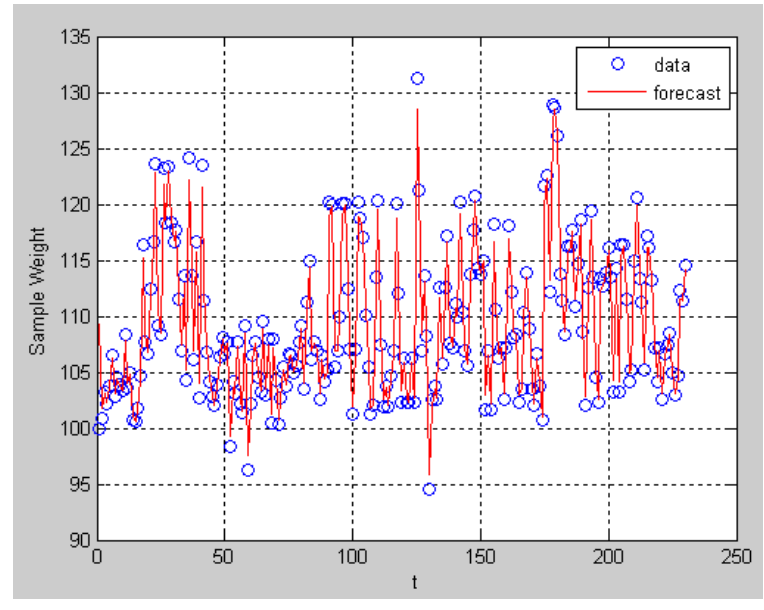

Figure 7 Forecast result of pesticide sample weight

\section{Conclusion}

ACO method can estimate exponential smoothing parameter on pesticides active ingredient and sample weight forecasts. From the simulation, on the first iteration, all ants choose parameter randomly. At the optimization process, we update pheromone until all ants choose the similar parameter so that process converges and variance approaches to zero. After ACO is applied, we obtain the optimal exponential smoothing parameter. The optimal exponential parameter can be applied in forecasting with minimum sum of squared error (SSE). The results of simulations are optimal exponential smoothing parameter is 0,9 and SSE of pesticide active ingredient and sample weight forecast are 0,77 and 194,34 respectively. The impact of this research is to plan the manufacturer to forecast pesticides active ingredient and sample weight in future time.

\section{References}

Anderson, D.R., Sweeney, D.J., 2012, An Introduction to Management Science, Cengage Learning, USA, ISBN: 978-1111-53224-6

Dorigo, M., Stutzle, T., 2004, Ant Colony Optimization, The MIT Press, London, ISBN: 0-262-04219-3

Elvural, B.C., Beyca, O.F., Zaim, S., 2016, Model Estimation of ARMA using Genetic Algorithms : A Case Study of Forecasting Natural Gas Consumption, Procedia-Social and Behavioral Sciences, 235, 537- 545

Montgomery, D.C., Jennings, C.L., Kulahci, M., 2015, Introduction to Time Series Analysis and Forecasting, John Wiley and Sons, New Jersey

Rahmalia, D., 2010, Pengendalian Kualitas Kadar Bahan Aktif dan Alumunium Foil pada Produksi Pestisida, Laporan Kerja Praktek Matematika ITS, Surabaya

Rahmalia, D., Herlambang, T., 2017, Application Ant Colony Optimization on

Estimation of Exponential Smoothing Parameter on Pesticide Characteristic Forecast using Ant Colony Optimization (ACO) 
Weight Selection of Optimal Control SEIR Epidemic Model, Proceeding the 7th Annual Basic Science International Conference 2017, ISSN : 2338-0128, diselenggarakan oleh Fakultas MIPA Universitas Brawijaya, Malang

Rao, S.S, 2009, Engineering Optimization Theory and Practice, John Wiley and Sons, New Jersey, ISBN: 978-0-47018352-6

Wu, B., Chang, C.L., 2002, Using Genetic Algorithm to Parameters (d,r) Estimation for Threshold Autoregressive Models, Computational Statistics \& Data Analysis, 38, 315-330 